\title{
Distribution of GAP-43 mRNA in the Brain Stem of Adult Rats as Evidenced by in situ Hybridization: Localization within Monoaminergic Neurons
}

\author{
Caterina Bendotti, Antonio Servadio, and Rosario Samanin \\ Istituto di Ricerche Farmacologiche "Mario Negri," 20157 Milan, Italy
}

\begin{abstract}
Using in situ hybridization, we examined the distribution of the mRNA encoding for the growth-associated protein GAP43 in the brain stem of adult rats. GAP-43 was expressed at the highest level in the nucleus raphe dorsalis (NDR), nucleus centralis superior (NCS), substantia nigra compacta (SNc), ventral tegmental area (VTA), and locus coeruleus (LC). An intermediate level of signal was detected over the periaqueductal gray, superior colliculi, and thalamic region, and no significant signal was detected in the substantia nigra pars reticulata and red nucleus. The hybridization signals of GAP43 mRNA and tryptophan hydroxylase mRNA completely overlapped in the NDR and NCS, and signals for GAP-43 mRNA and tyrosine hydroxylase mRNA overlapped in the SNC, VTA, and LC. The disappearance of the hybridization signal for GAP-43 mRNA after intracerebroventricular injections of the neurotoxins 5,7-dihydroxytryptamine (5,7-DHT) or 6-hydroxydopamine (6-OHDA) indicated that high levels of GAP-43 are synthesized in the serotonergic neurons of the raphe nuclei and in the catecholaminergic neurons of the SNC, VTA, and LC. In light of the role of GAP-43 in axonal outgrowth, modulation of signal transduction, and release of different neurotransmitters in the adult CNS, this phosphoprotein might be involved in the functional plasticity and synaptic transmission of monoaminergic neurons.
\end{abstract}

The growth-associated protein GAP-43 (also known as GAP$48, \mathrm{~F} 1, \mathrm{~B} 50$, and pp46) is a neuron-specific phosphoprotein of the presynaptic membrane that plays a role in axonal outgrowth during development and nerve regeneration (see reviews by Benowitz and Routtenberg, 1987; Skene, 1989). Although GAP43 levels are highest in developing neurons during synaptogenesis, considerable levels are present in nerve terminals in some regions of the mature CNS (Jacobson et al., 1986; Oestreicher and Gispen, 1986; Benowitz et al., 1988; McGuire et al., 1988). GAP-43 is a major substrate of protein kinase C (Aloyo et al., 1983; Akers and Routtenberg, 1987), and its phosphorylation has been implicated in the regulation of transmembrane signal

\footnotetext{
Received May 14, 1990; revised Sept. 26, 1990; accepted Oct. 5, 1990.

We wish to thank Dr. R. Neve (Children's Hospital, Boston, MA) for the rat cDNA for GAP-43, Dr. J. Mallet and Dr. M. Darmon (CNRS, Gif-sur-Yvette, France) for the rat cDNA for tryptophan hydroxylase, and Dr. D. Chikaraishi (Tufts University Medical School, Boston, MA) for the rat cDNA for tyrosine hydroxylase. This work was supported by the National Research Council (CNR, Rome, Italy) Progetto Speciale di Comitato "Meccanismi di release dei neurotrasmettitori e loro controllo." A.S. is the recipient of a fellowship from Banca Popolare di Milano.

Correspondence should be addressed to Dr. Caterina Bendotti, Istituto di Ricerche Farmacologiche "Mario Negri," Via Eritrea 62, 20157 Milan, Italy. Copyright (C) 1991 Society for Neuroscience $0270-6474 / 91 / 110600-08 \$ 03.00 / 0$
}

transduction (Oestreicher et al., 1983). Recently, GAP-43 was found to be identical to the neural-specific calmodulin-binding protein P-57 (Alexander et al., 1987; Cimler et al., 1987), suggesting that it influences $\mathrm{Ca}^{2+}$-calmodulin-regulated processes at presynaptic terminals (De Lorenzo, 1982). Phosphorylation of GAP-43 is associated with neurotransmitter release in rat hippocampal slices (Dekker et al., 1989a; Heemskerk et al., 1990), and a recent study showed that antibodies to GAP-43/ B50 inhibited noradrenaline release from adult rat cortical synaptosomes (Dekker et al., 1989b). This study suggested that GAP-43 is found in monoaminergic nerve terminals, where it modulates transmitter release.

Several studies have shown that GAP-43 immunoreactivity is present in certain neuropil areas. In the rat, levels of GAP43 are highest in layer 1 of the neocortex, the CA1 ficld of the hippocampus, and internal molecular layer of the dentate gyrus, as well as in subcortical structures, including the caudate-putamen, septal area, nucleus accumbens, olfactory tubercle, amygdala, and hypothalamus (Oestreicher and Gispen, 1986; Benowitz et al., 1988; McGuire et al., 1988). A comparison of the distribution of GAP-43 mRNA and the protein itself in the adult rat brain (Rosenthal et al., 1987; Neve et al., 1988) suggests that, in some regions (e.g., in the hippocampus), the protein is found in terminals of extrinsic neurons. There is no information on the localization of GAP-43 mRNA in brain-stem regions where most monoaminergic neurons innervating the forebrain originate.

In the present study, we used the in situ hybridization technique to locate cell bodies containing high levels of GAP-43 mRNA in the brain stem of adult rats. To characterize the neuronal population synthesizing GAP-43, wc compared the expression of the GAP-43 transcript with that of mRNA coding for tyrosine hydroxylase (TH), the rate-limiting enzyme in catecholamine biosynthesis, or for tryptophan hydroxylase (TPH), the rate-limiting enzyme in serotonin synthesis, in rats with selective lesions of catecholamine- or serotonin-containing neurons.

\section{Materials and Methods}

Probe preparation. Riboprobes complementary (cRNA) to GAP-43, TPH, or TH mRNA were used for the hybridization. Rat GAP-43 cDNA (clone GA11B; Neve et al., 1987) subcloned in pGEM 3, rat cDNA TPH subcloned in the SPT 18 vector (TPH-1; Darmon et al., 1988), and rat cDNA TH subcloned in pSP65 (containing nucleotides 1246-1520 from the sequence of Grima et al., 1985) were kindly provided by Dr. R. Neve (Children's Hospital, Boston, MA), Dr. Mallet (CNRS, Gifsur-Yvette, France), and Dr. D. Chikaraishi (Tufts University Medical School, Boston, MA), respectively.

Radiolabeled cRNAs were synthesized in vitro from linearized plasmids by the Promega protocol for RNA transcription using ${ }^{35} \mathrm{~S}$-UTP 

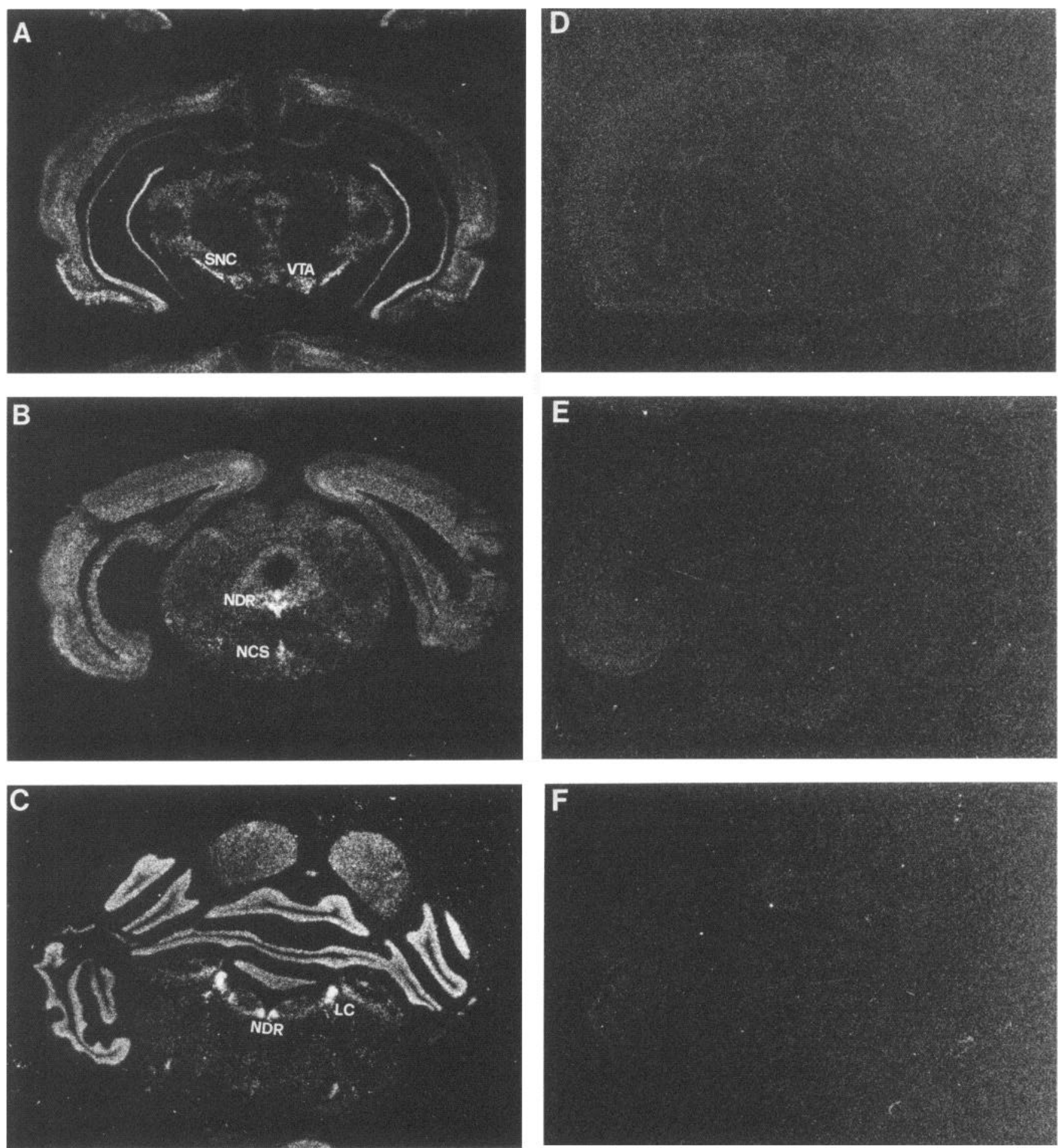

Figure 1. In situ hybridization of ${ }^{35} \mathrm{~S}$ cRNA probe for GAP-43 mRNA applied to coronal sections of adult rat brain stem. Note the intense hybridization signal (white regions) over the SNc and VTA $(A)$, NDR and NCS $(B)$, and LC $(C)$. A distinct signal is also detected over the periaqueductal gray and the superior colliculi. Outside the brain stem, the highest signal appears over the CA3 and CA4 pyramidal layers of hippocampus, the cingulate, piriform, and entorhinal cortices, and the granule cell layer of the cerebellum. $D-F$ represent brain coronal sections hybridized with ${ }^{35} \mathrm{~S}$-labeled sense-strand RNA for GAP-43 mRNA. Note the lack of hybridization signal over the brain structures described above.

$(1000 \mathrm{Ci} / \mathrm{mmol})$ and the specific DNA-dependent RNA polymerases. The lengths of the probes were $0.7,1.0$, and 0.1 kilobases for GAP-43, $\mathrm{TPH}$, and TH respectively, and the specific activity was about $10^{8} \mathrm{cpm} /$ $\mu \mathrm{g}$ of template.

Tissue preparation. Male Sprague-Dawley rats (CD/COBS, Charles River, Italy), 250-300 gm, were used. Selective monoaminergic lesions were made by injecting into the cerebral ventricles of anesthetized rats (Equitensin, $1.8 \mathrm{ml} / \mathrm{kg}$ ) $20 \mu \mathrm{l}$ of $0.1 \%$ ascorbic acid containing $150 \mu \mathrm{g}$ of 5,7-dihydroxytryptamine (5,7-DHT) or $200 \mu \mathrm{g}$ of 6-hydroxydopamine (6-OHDA), selective neurotoxins for serotonergic and catecholaminergic neurons, respectively. Control rats received $20 \mu \mathrm{l}$ of $0.1 \%$ ascorbic acid. Desmethylimipramine $(25 \mathrm{mg} / \mathrm{kg})$, an inhibitor of nor- 


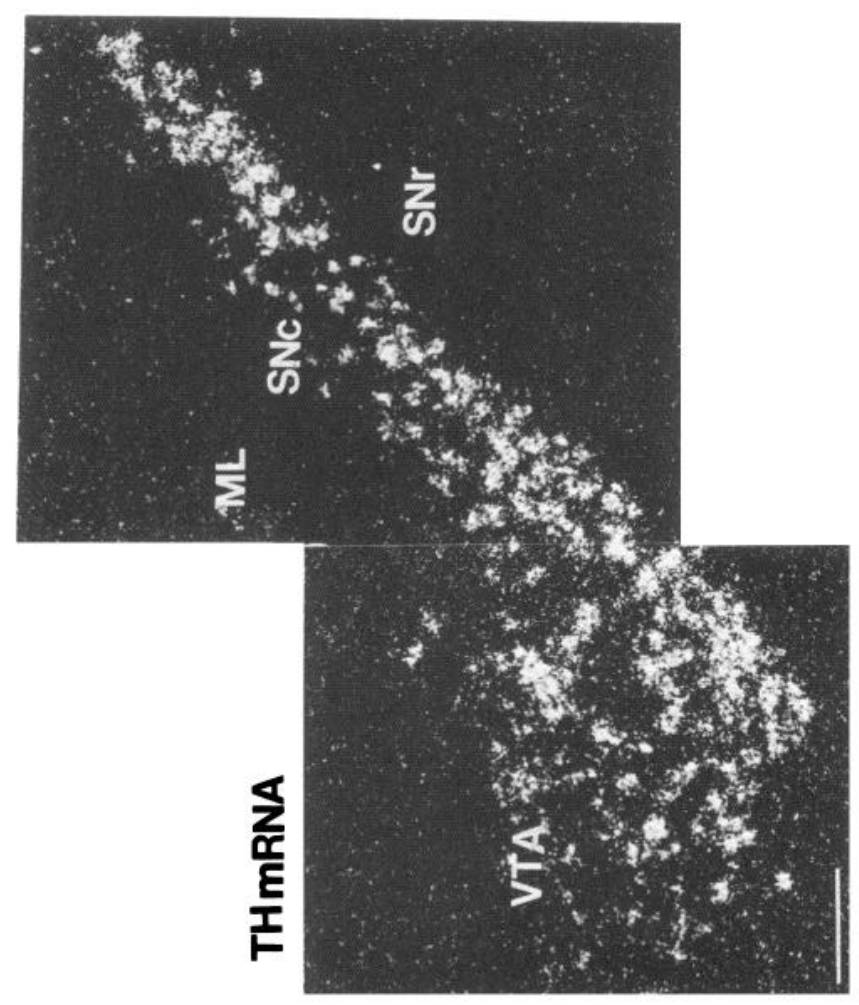

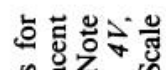

高要这 कै 牙嵒

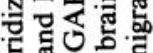
全产岁思 ○《్

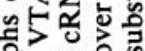

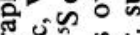

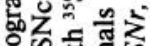

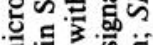

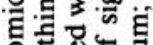

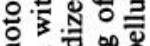
돔을. 근응

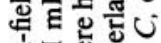
密它婇 Oि

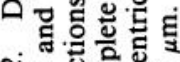

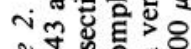

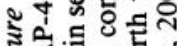

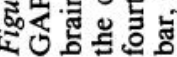
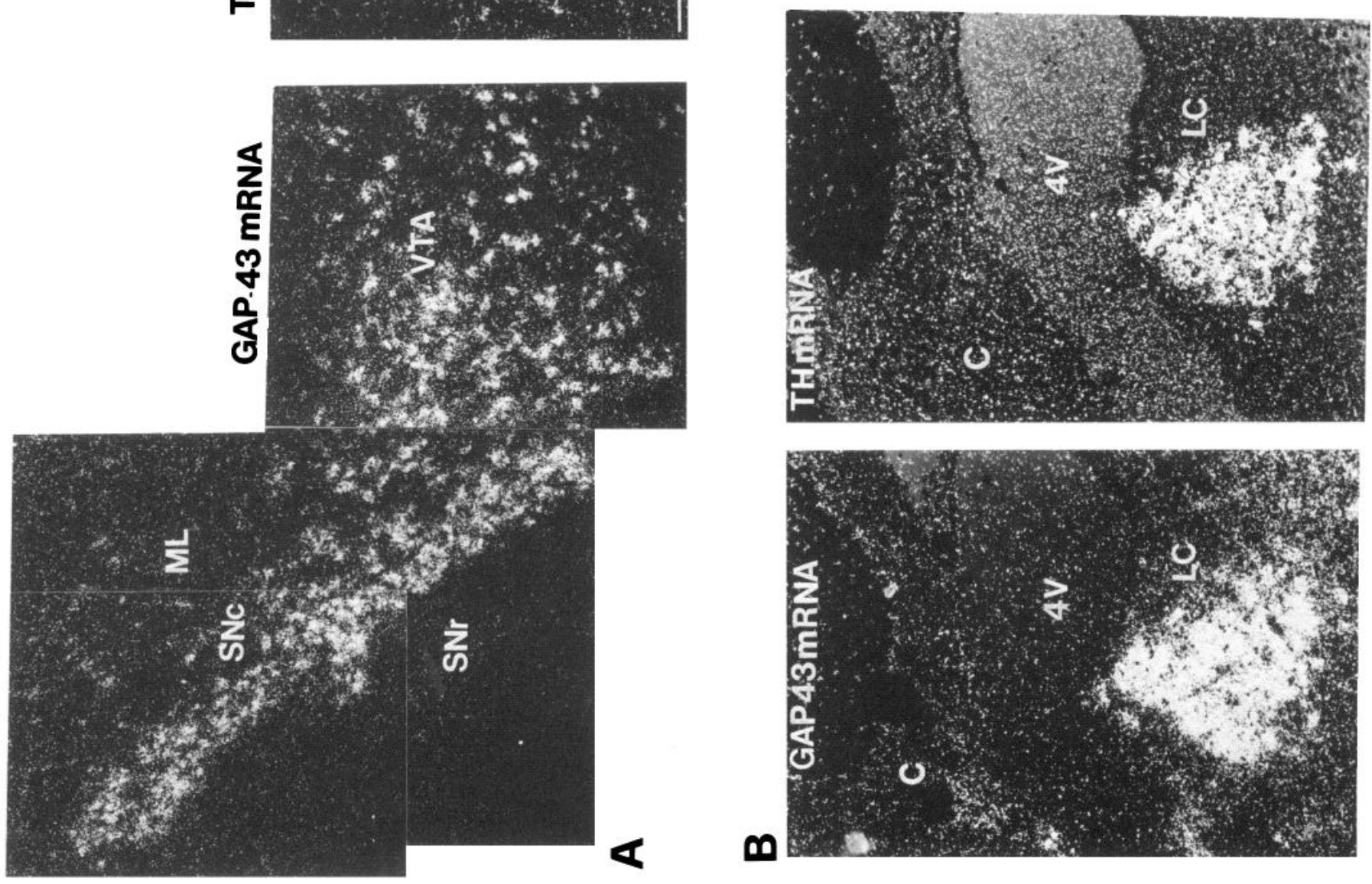

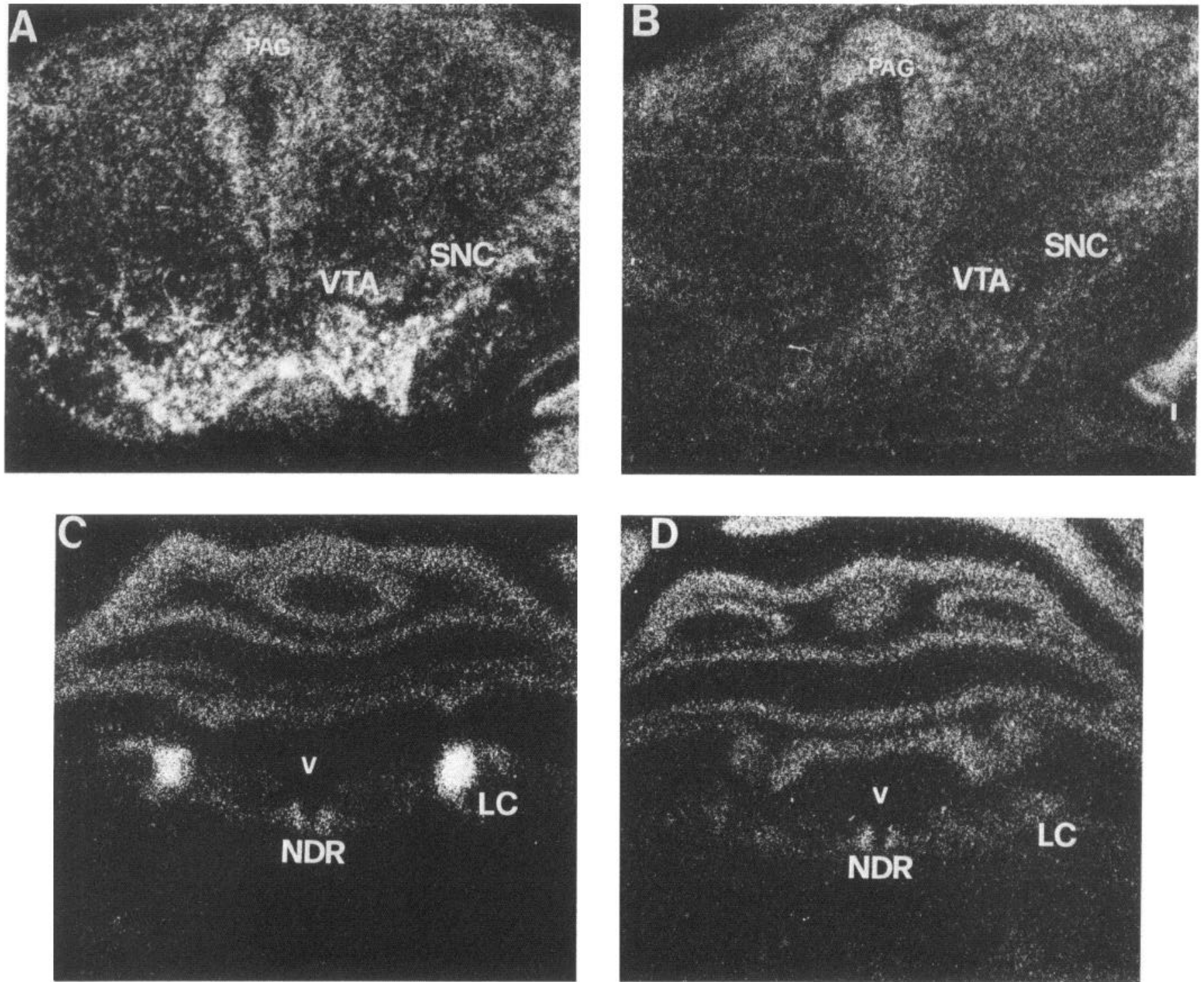

Figure 3. High magnification of film autoradiograms of coronal brain-stem sections at level of SNc and VTA (top) and LC (bottom) hybridized with ${ }^{35}$ S cRNA GAP-43 probe: comparison of controls $(A, C)$ and 6-OHDA-treated rats $(B, D)$. The signal over the SNc, VTA, and LC almost completely disappears in 6-OHDA-treated rats. $P A G$, periaqueductal grey; $V$, fourth ventricle.

adrenaline uptake, was injected intraperitoneally $30 \mathrm{~min}$ before $5,7-$ DHT to prevent damage to noradrenergic neurons. Pargyline $(50 \mathrm{mg} /$ $\mathrm{kg}$ ), an inhibitor of monoamino-oxidase, was injected intraperitoneally $30 \mathrm{~min}$ before 6-OHDA to enhance the effect of the neurotoxin on dopamine-containing neurons. Seven to $10 \mathrm{~d}$ later, the rats were killed by decapitation, and the brain stems were dissected out and rapidly frozen in isopentane kept on dry ice. The cortex, caudate-putamen, and hippocampus were used for assessing the extent of the lesions through the measurement of serotonin and catecholamine levels. Briefly, the tissue samples were homogenized by sonication in $300 \mu \mathrm{l} 0.1 N \mathrm{HClO}_{4}$ and centrifuged at $15,000 \times g$ for $10 \mathrm{~min}$. Aliquots of $20 \mu \mathrm{l}$ supernatant were directly injected in a reverse-phase column, and serotonin and catecholamines were measured as described by Achilli et al. (1985). Brain-stem coronal sections $(14 \mu \mathrm{m})$ were cut, thaw mounted on gelatincoated microscope slides, and kept dessicated at $-80^{\circ} \mathrm{C}$ until the day of the in situ hybridization experiment.

In situ hybridization. Mounted sections were brought to room temperature and rapidly immersed in $4 \%$ paraformaldehyde freshly prepared in $0.1 \mathrm{~m}$ phosphate-buffered saline (PBS). After $5 \mathrm{~min}$, sections were rinsed twice in PBS, acetylated in $0.25 \%$ acetic anhydride in 0.1 M triethanolamine $/ 0.9 \% \mathrm{NaCl}(\mathrm{pH}, 8)$ for $10 \mathrm{~min}$, and dehydrated and delipidated in graded ethanol and chloroform. They were then air dried and hybridized with the ${ }^{35} \mathrm{~S}$-radiolabeled probes at $55^{\circ} \mathrm{C}$ overnight in a buffer containing $4 \times$ SSC $(0.6 \mathrm{~m}$ sodium chloride, $0.06 \mathrm{~m}$ sodium citrate), $50 \%(\mathrm{v} / \mathrm{v})$ deionized formamide, $10 \%(\mathrm{w} / \mathrm{v})$ dextran sulphate, $1 \times$ Denhardt's solution $(0.02 \%$ ficoll, $0.02 \%$ polyvinylpyrrolidone, $0.02 \%$ bovine serum albumin), $500 \mu \mathrm{g} / \mathrm{ml}$ single-stranded salmon sperm DNA, $250 \mu \mathrm{g} / \mathrm{ml} t \mathrm{RNA}$, and $10 \mathrm{~mm}$ dithiothreitol. The probe concen-

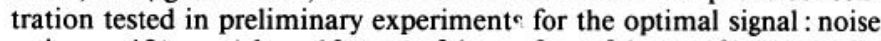
ratio was $10^{4} \mathrm{cpm} / \mu \mathrm{l}$ per $10 \mathrm{~mm}^{2}$ of the surface of the parafilm coverslip mounted over the sections before the overnight incubation.

After the incubation, the coverslips were removed by dipping the slides in $1 \times$ SSC containing $10 \mathrm{~mm} 2$-mercaptoethanol. The sections were then washed in the same solution for $30 \mathrm{~min}$ at room temperature and incubated at $37^{\circ} \mathrm{C}$ for $30 \mathrm{~min}$ in RNase A $(20 \mu \mathrm{g} / \mathrm{ml})$ dissolved in RNase buffer $(0.5 \mathrm{~m} \mathrm{NaCl}, 10 \mathrm{~mm}$ Tris- $\mathrm{HCl}, \mathrm{pH} 8.0,1 \mathrm{~mm}$ EDTA), followed by $30 \mathrm{~min}$ incubation in RNase buffer at $37^{\circ} \mathrm{C}$. After $30 \mathrm{~min}$ washing in $1 \times \mathrm{SSC}$ at room temperature, the sections underwent a high-stringency wash in $0.5 \times \mathrm{SSC}$ at $65^{\circ} \mathrm{C}$ for $30 \mathrm{~min}$. The slides were finally rinsed in $0.5 \times \mathrm{SSC}$ at room temperature, dried under an airstream, and exposed to Beta-max film (Amersham) for autoradiography. Films were developed after $7 \mathrm{~d}$, and the sections were dipped in NTB 


\section{GAP.43 mRNA}
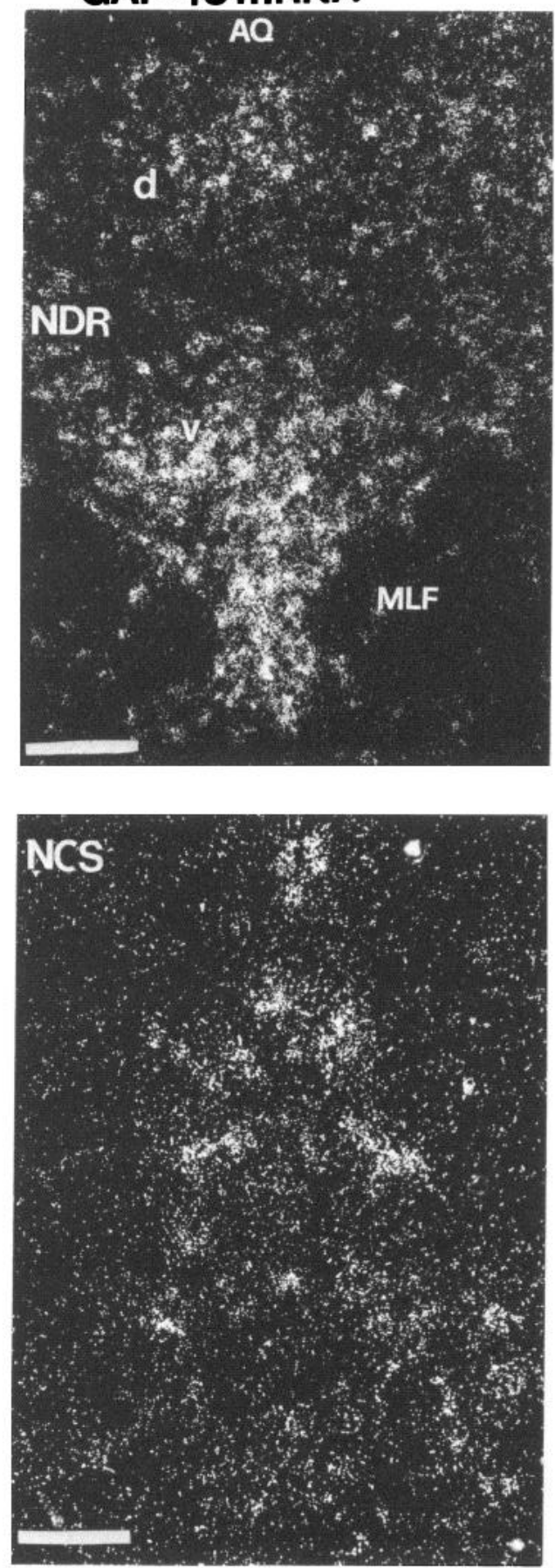

TPH mRNA
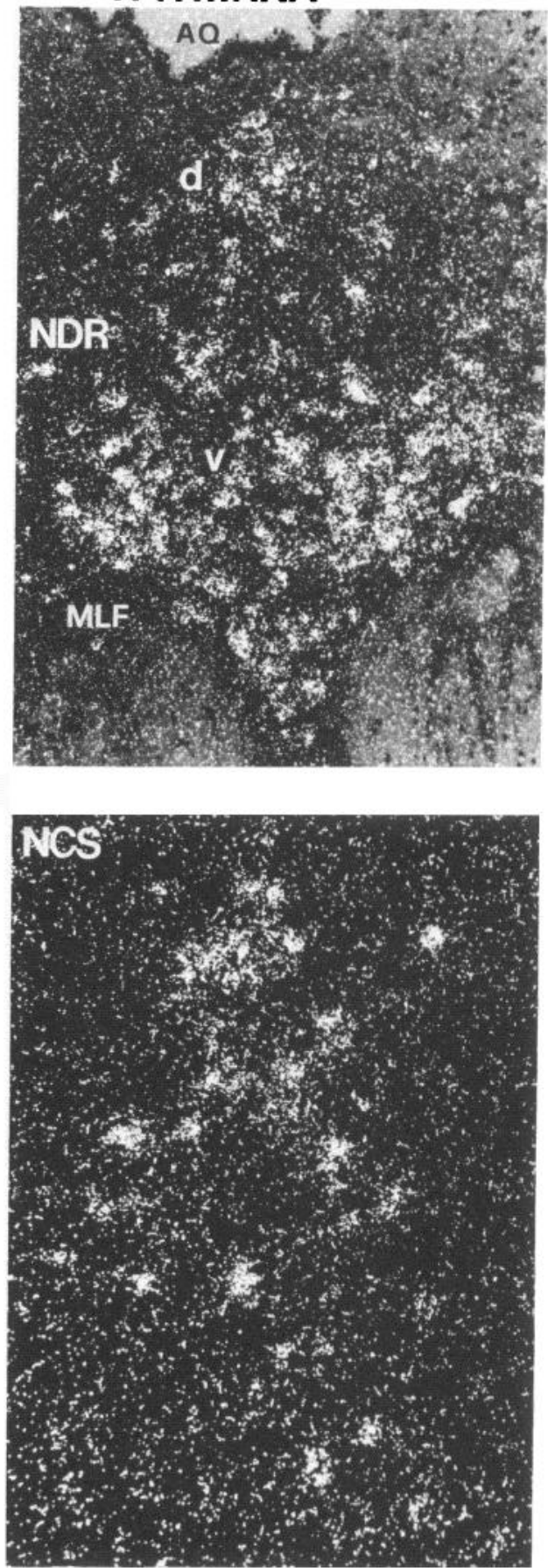

Figure 4. Dark-field photomicrographs of hybridization signals for GAP43 and TPH mRNA within NDR (top) and NCS (bottom). Note the similar localization of GAP-43- and TPH mRNA-positive neurons, with the highest density in the dorsal $(d)$ and ventral $(v)$ regions of the NDR and a scattered distribution in the NCS. The clusters of grains represent individual positive cells. $A Q$, aqueduct of Silvius. Scale bars: $200 \mu \mathrm{m}, t o p ; 100 \mu \mathrm{m}$, bottom.

2 emulsion (Kodak; diluted 1:1 with water), kept at $4^{\circ} \mathrm{C}$ for $7-20 \mathrm{~d}$, and then developed and stained with cresyl violet. The sections were examined by light- and dark-field microscopy.

\section{Results}

Figure 1 shows an overview of the expression of GAP-43 mRNA at different levels of the adult rat brain stem. The hybridization signal was highest in the substantia nigra pars compacta (SNc), ventral tegmental area (VTA), nuclei raphe dorsalis (NDR), nucleus centralis superior (NCS), and locus coeruleus (LC). An intermediate signal was detected over the periaqueductal gray, superior colliculi, and thalamic region, and no significant hybridization was observed over the substantia nigra pars reticulata and red nucleus. No attempt was made in this study to detect GAP-43 mRNA hybridization signal in serotonin and noradrenaline or adrenaline-containing cells beyond the LC. Outside the brain stem, a high-density signal appeared over the CA3 and CA4 pyramidal layers of the hippocampus and over the granule cell layer of the cerebellar cortex. Density was relatively high over layers II-V of the cerebral cortex, with the highest signal 
GAP. 43 mRNA
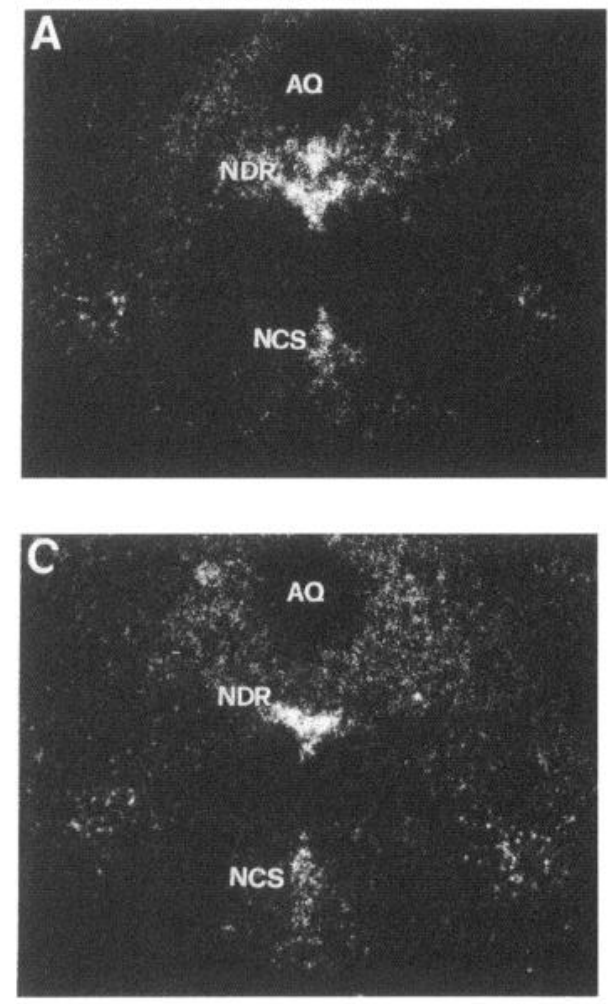

\section{TPH mRNA}
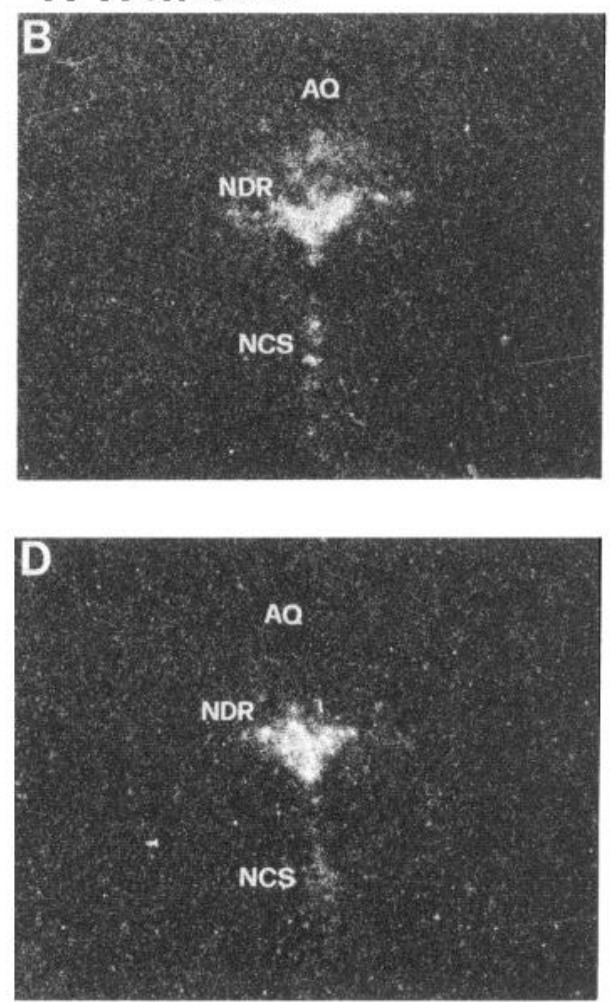

Figure 5. Film autoradiograms showing hybridization signals for GAP-43 and TPH mRNA over NDR and NCS of rats given icv injections of 5,7-DHT $(C, D)$ or vehicle $(A, B)$. Note the complete disappearance of the GAP-43 and TPH mRNA signals in the dorsal region of the NDR, just below the aqueduct of Silvius $(A Q)$, in the 5,7-DHT-treated rats. No differences were observed between controls and 5,7-DHT-injected rats in the ventral region of the NDR and in the NCS for GAP-43 mRNA. The hybridization signal for TPH mRNA was increased in the ventral NDR, but not in the NCS, in 5,7-DHTtreated rats. concentrated in the cingulate, piriform, and entorhinal cortices. The specificity of the signal was demonstrated by the lack of hybridization over these brain structures using the sense-strand probe, which is identical to the GAP-43 mRNA (Fig. 1).

At the level of the SNc, VTA, and LC, a similar pattern of distribution was observed for GAP-43 mRNA and TH mRNA (Fig. 2). In the SNc, a large number of positive neurons were organized along a lateral transverse line just below the medial lemniscus (ML), while in the VTA, positive neurons appeared more diffusely distributed near the midline (Fig. $2 A$ ). Densely packed positive cells located bilaterally on the floor of the fourth ventricle were observed in the LC (Fig. $2 B$ ). These observations are in complete agreement with the anatomical organization of the dopaminergic and noradrenergic systems evidenced by immunocytochemical studies (Swanson, 1976; Steinbush and Nieuwenhuys, 1983). Selective lesions of catecholaminergic neurons, induced by intracerebroventricular (icv) injection of the neurotoxin 6-OHDA, caused complete disappearance of the signal for GAP 43 mRNA over the SNc, the VTA, and the LC (Fig. 3). Likewise, when adjacent brain sections from 6-OHDAlesioned rats were hybridized for TH mRNA, no signal was observed over these structures (data not shown). The 6-OHDAlesioned rats showed an $88 \%$ reduction of noradrenaline levels in the hippocampus and a $90 \%$ reduction of dopamine content in the striatum compared to vehicle-treated rats. In vehicletreated rats, noradrenaline levels in the hippocampus were 262 $\pm 25 \mathrm{ng} / \mathrm{gm}$ tissue, and dopamine levels in the striatum were $4240 \pm 306 \mathrm{ng} / \mathrm{gm}$ tissue.

Detailed microscopic analysis of GAP-43 mRNA expression over the raphe nuclei showed a high concentration of cells with high grain density within the NDR, with a distribution similar to that observed for TPH mRNA (Fig. 4, top). A dense ventromedial cell cluster was observed between and just above the medial longitudinal fasciculus (MLF), and a smaller dorsomedial (d) component was located just below the cerebral aqueduct. Microscopic examination of single neurons containing GAP-43 mRNA or TPH mRNA from different regions of the NDR revealed no apparent differences in the grain density per cell. In the NCS, the cells containing GAP-43 mRNA, like TPH mRNA, were less numerous and were scattered along the midline (Fig. 4, bottom).

In the NDR of 5,7-DHT-treated rats, the GAP-43 mRNA hybridization signal virtually disappeared in the dorsomedial region, just below the aqueduct, though no change was observed in the ventromedial region of the NDR d (Fig. 5). A similar pattern was observed for the distribution of TPH mRNA in the NDR of 5,7-DHT-treated rats, indicating a partial survival of serotonergic neurons in the ventromedial region. No detectable changes for both TPH and GAP-43 mRNA expression were observed in the NCS of 5,7-DHT-lesioned rats compared with controls. In 5,7-DHT-lesioned rats, serotonin levels in the cortex, caudate-putamen, and hippocampus were, respectively, 60 , 70 , and $90 \%$ lower than controls. Serotonin levels (ng/gm tissue $\pm \mathrm{SE}$ ) in these 3 brain regions in vehicle-treated rats were 357 $\pm 1,213 \pm 3$, and $235 \pm 17$ respectively.

\section{Discussion}

The present results demonstrate a marked regional heterogeneity of GAP-43 mRNA expression in the brain stem of adult rats. Levels of the GAP-43 transcript were highest in the SNc, 
VTA, and LC, with a distribution similar to that of TH mRNA and, in the NDR and NCS, paralleling the expression of TPH mRNA.

Although neurons other than those that are catecholaminergic or serotonergic are located in these brain regions (Lindvall and Björklund, 1983; Steinbush and Nieuwenhuys, 1983), the disappearance of the hybridization signal for GAP-43 mRNA after selective lesions by 6-OHDA or 5,7-DHT indicated that high levels of GAP-43 are synthesized in the catecholaminergic neurons of the SNc, VTA, and LC and in serotonergic neurons of the raphe nuclei.

The persistence of GAP-43 mRNA and TPH mRNA signal in the ventromedial region of the NDK and in the NCS after 5,7-DHT treatment compared to the dorsal region of the NDR suggests a selective vulnerability of some serotonergic neurons to the neurotoxin. Previous studies on the immunocytochemical distribution of GAP-43 showed dense staining in different areas of the forebrain (Jacobson et al., 1986; Oestreicher and Gispen, 1986; Benowitz et al., 1988; McGuire et al., 1988). Although these regions receive projections from different neuronal populations and intrinsic neurons may contain high levels of GAP43 , the present findings suggest that part of this immunoreactivity derives from the monoaminergic neurons. In particular, the high expression of GAP-43 mRNA in the SNc could account for the marked immunoreactivity for GAP-43 in the caudateputamen, an area that receives a dense innervation from the SNc (Björklund and Lindvall, 1984). However, this area is heavily innervated by cortical neurons that have been shown to express high levels of GAP-43 mRNA (Neve et al., 1987, 1988; Rosenthal et al., 1987). A contribution to striatal GAP-43 immunoreactivity can also derive from intrinsic neurons, as Ncve et al. (1987), using RNA blot analysis, reported that GAP-43 mRNA is highly expressed in the adult rat striatum.

In contrast to the high expression of GAP-43 within the monoaminergic systems, the present study showed a lack of signal within the substantia nigra pars reticulata, where the density of GABA neurons is high (Mugnaini and Oertel, 1985). This suggests that this prolein has a functional role within certain neurotransmitter-containing neurons in the adult CNS, but not others.

The present findings raise several questions concerning the significance of the high GAP-43 mRNA expression in monoaminergic neurons of the adult rat brain. In neurons capable of regenerating their axons after injury, a remarkable increase of synthesis of GAP-43 and its transport to nerve terminal membranes has been shown (Skene and Willard, 1981a,b; Benowitz and Lewis, 1983; Tetzlaff et al., 1989), whereas enhanced synthesis of GAP-43 was not detected in nerves that failed to regenerate (Skene and Willard, $1981 \mathrm{~b}$; Kalil and Skene, 1986; Reh et al., 1987). The high levels of expression of GAP-43 within the monoaminergic neurons suggest that this protein could play a role in the regenerative sprouting of these cells. Azmitia et al. (1978) found significant sprouting of serotonergic neurons in the adult rat brain after lesioning ascending serotonergic pathways with $5,7-\mathrm{DHT}$.

Central catecholamine neurons can also show regeneration after electrolytic lesions of SNc and VTA axons (Katzman et al., 1971). Collateral sprouting from dopaminergic neurons of the VTA has been shown 3-4 weeks after unilateral olfactory bulbectomy, indicating a remarkable plasticity of these neurons (Gilad and Reis, 1979). The high levels of GAP-43 expression in VTA dopaminergic neurons suggest that this protein could play a part in their capacity for axonal sprouting.

One week after icv injection of 6-OHDA, GAP-43 and TH mRNA signals over the SNc and VTA disappeared, probably reflecting a degeneration of almost all the dopaminergic neurons in these areas. These data confirm previous evidence of the complete elimination of TH mRNA in the SNc and VTA ipsilateral to the 6-OHDA injection in this region (Lindefors et al., 1989).

GAP-43 is a substrate of protein kinase C (Aloyo et al., 1983; Akers and Routtenberg, 1987) localized in certain presynaptic membranes (Gispen et al., 1985). An association between GAP43 phosphorylation and neurotransmitter release has been reported in adult rat hippocampal slices and synaptosomes (Dekker et al., 1989a; Heemskerk et al., 1990). It has also been shown that antibody to GAP-43 reduced the release of ${ }^{3} \mathrm{H}$-noradrenaline from cortical synaptosomes (Dekker et al., 1989b). Thus, the high expression of GAP-43 in neurons of the LC could indicate that this protein may play an important role in the modulation of noradrenaline release.

Recent studies show that activation of protein kinase $\mathrm{C}$ by phorbol esters can induce significant serotonin release from rat brain cortical slices or rabbit hippocampal slices, and PKC inhibitors reduced the $\mathrm{K}^{+}$-induced release of serotonin (Wang and Friedman, 1987). Likewise, protein kinase $C$ has been implicated in the release of dopamine from the nigrostriatal dopamine system or mesocortical dopaminergic neurons after injection of drugs that affect dopamine release in vivo (Giambalvo, 1988; Talmaciu et al., 1989). Considering the high level of expression of GAP-43 mRNA in the serotonergic neurons of the raphe nuclei, as well as in the dopaminergic neurons of the SNc and VTA, this protein is likely to be involved in the mechanisms controlling the release of these neurotransmitters.

The present results provide the first direct evidence of the localization of GAP-43 in specific neurotransmitter-containing neurons of the adult rat nervous system. Because of the role played by this phosphoprotein in the process of axonal outgrowth (Benowitz and Routtenberg, 1987; Skene, 1989), the high expression of GAP-43 mRNA in serotonergic, dopaminergic, and noradrenergic neurons may explain the regenerative sprouting and synaptic reorganization seen after damage to these systems. The fact that GAP-43 is highly expressed in monoaminergic neurons in the absence of neuronal lesions, together with evidence associating this protein with neurotransmitter release, suggests that it is involved in physiological processes regulating the synaptic function of these neurotransmitters.

\section{References}

Achilli G, Perego C, Ponzio F (1985) Application of the dual-cell coulometric detector: a method for assaying monoamines and their metabolites. Anal Biochem 148:1-9.

Akers RF, Routtenberg A (1987) Calcium-promoted translocation of protein kinase $C$ to synaptic membranes: relation to the phosphorylation of an endogenous substrate (protein $F 1$ ) involved in synaptic plasticity. J Neurosci 7:3976-3983.

Alexander KA, Cimler BM, Meier KE, Storm DR (1987) Regulation of calmodulin binding to P-57. A neurospecific calmodulin binding protein. J Biol Chem 262:6108-6113.

Aloyo VJ, Zwicrs H, Gispen WH (1983) Phosphorylation of B-50 protein by calcium-activated, phospholipid-dependent protein kinase and B-50 protein kinase. J Neurochem 41:649-653.

Azmitia EC, Buchan AM, Williams JH (1978) Structural and func- 
tional restoration by collateral sprouting of hippocampal 5-HT axons. Nature 274:374-376.

Benowitz LI, Lewis ER (1983) Increased transport of 44,000- to 49,000dalton acidic proteins during regeneration of the goldfish optic nerve: a two dimensional gel analysis. J Neurosci 3:2153-2163.

Benowitz LI, Routtenberg A (1987) A membrane phosphoprotein associated with neural development, axonal regeneration, phospholipid metabolism, and synaptic plasticity. Trends Neurosci 10:527532.

Benowitz LI, Apostolides PJ, Perrone-Bizzozero N, Finklestein SP, Zwiers $H$ (1988) Anatomical distribution of the growth-associated protein GAP-43/B-50 in the adult rat brain. J Neurosci 8:339-352.

Björklund A, Lindvall O (1984) Dopamine-containing systems in the CNS. In: Handbook of chemical neuroanatomy, Vol 2, Classical transmitters in the CNS, Pt 1 (Björklund A, Hökfelt T, eds), pp 55-122. Amsterdam: Elsevier.

Cimler BM, Giebelhaus DH, Wakim BT, Storm DR, Moon RT (1987) Characterization of murine cDNAs encoding P-57, a neural-specific calmodulin-binding protein. J Biol Chem 262:12158-12163.

Darmon MC, Guibert B, Leviel V, Ehret M, Maitre M, Mallet J (1988) Sequence of two mRNAs encoding active rat tryptophan hydroxylase. J Neurochem 51:312-316.

Dekker LV, De Graan PNE, Versteeg DHG, Oestreicher AB, Gispen WH (1989a) Phosphorylation of B-50 (GAP43) is correlated with neurotransmitter release in rat hippocampal slices. J Neurochem 52: 24-30.

Dekker LV, De Graan PNE, Oestreicher AB, Versteeg DHG, Gispen WH $(1989 \mathrm{~b})$ Inhibition of noradrenaline release by antibodies to B-50 (GAP-43). Nature 342:74-76.

De Lorenzo RJ (1982) Calmodulin in neurotransmitter release and synaptic function. Fed Proc 41:2265-2272.

Giambalvo CT (1988) Protein kinase C and dopamine release-II. Effect of dopamine acting drugs in vivo. Biochem Pharmacol 37:40094017.

Gilad GM, Reis DJ (1979) Collateral sprouting in central mesolimbic dopamine neurons: biochemical and immunocytochemical evidence of changes in the activity and distribution of tyrosine hydroxylase in terminal fields and in cell bodies of A10 neurons. Brain Res 160:1736.

Gispen WH, I eunissen JLM, Oestreicher AB, Verkleij AJ, Zwiers H (1985) Presynaptic localization of B-50 phosphoprotein: the (ACTH)sensitive protein kinase substrate involved in rat brain polyphosphoinositide metabolism. Brain Res 328:381-385.

Grima B, Lamouroux A, Blanot F, Biguet NF, Mallet J (1985) Complete coding sequence of rat tyrosine hydroxylase mRNA. Proc Natl Acad Sci USA 82:617-621.

Heemskerk FMJ, Schrama LH, Gianotti C, Spierenburg H, Versteeg DHG, De Graan PNE, Gispen WH (1990) 4-Aminopyridine stimulates B-50 (GAP43) phosphorylation and $\left[{ }^{3} \mathrm{H}\right]$ noradrenaline release in rat hippocampal slices. J Neurochem 54:863-869.

Jacobson RD, Virag I, Skene JHP (1986) A protein associated with axon growth, GAP-43, is widely distributed and developmentally regulated in rat CNS. J Neurosci 6:1843-1855.

Kalil K, Skene JHP (1986) Elevated synthesis of an axonally transported protein correlates with axon outgrowth in normal and injured pyramidal tracts. J Neurosci 6:2563-2570.

Katzman R, Björklund A, Owman CH, Stenevi U, West KA (1971) Evidence for regenerative axon sprouting of central catecholamine neurons in the rat mesencephalon following electrolytic lesions. Brain Res 25:579-596.

Lindefors N, Brene S, Herrera-Marschitz M, Persson H (1989) Region specific regulation of glutamic acid decarboxylase mRNA expression by dopamine neurons in rat brain. Exp Brain Res 77:611-620.
Lindvall O, Björklund A (1983) Dopamine- and norepinephrine-containing neuron systems: their anatomy in the rat brain. In: Chemical neuroanatomy (Emson PC, ed), pp 229-255. New York: Raven.

McGuire CB, Snipes GJ, Norden JJ (1988) Light-microscopic immunolocalization of the growth- and plasticity-associated protein GAP43 in the developing rat brain. Dev Brain Res 41:277-291.

Mugnaini E, Oertel WH (1985) An atlas of the distribution of GABAergic neurons and terminals in the rat CNS as revealed by GAD immunohistochemistry. In: Handbook of chemical neuroanatomy, Vol 4, GABA and neuropeptides in the CNS, Pt 1 (Björklund A, Hökfelt T, eds), pp 436-595. Amsterdam: Elsevier.

Neve RL, Perrone-Bizzozero NI, Finklestein S, Zwiers H, Bird E, Kurnit DM, Benowitz LI (1987) The neuronal growth-associated protein GAP-43 (B-50,F1): neuronal specificity, developmental regulation and regional distribution of the human and rat mRNAs. Mol Brain Res 2:177-183.

Neve RL, Finch EA, Bird ED, Benowitz LI (1988) Growth-associated protein GAP-43 is expressed selectively in associative regions of the adult human brain. Proc Natl Acad Sci USA 85:3638-3642.

Oestreicher AB, Gispen WH (1986) Comparison of the immunocytochemical distribution of the phosphoprotein B- 50 in the cerebellum and hippocampus of immature and adult rat brain. Brain Res 375 : 267-279.

Oestreicher AB, Van Dongen CJ, Zwiers H, Gispen WH (1983) Affinity-purified anti-B-50 protein antibody: interference with the function of the phosphoprotein B-50 in synaptic plasma membranes. J Neurochem 41:331-340.

Reh TA, Redshaw JD, Bisby MA (1987) Axons of the pyramidal tract do not increase their transport of growth-associated proteins after axotomy. Mol Brain Res 2:1-6.

Rosenthal A, Chan SY, Henzel W, Haaskell C, Kuang WJ, Chen E, Wilcox JN, Ulrich A, Goeddel DV, Routtenberg A (1987) Primary structure and mRNA localization of protein $F 1$, a growth-related protein kinase $\mathrm{C}$ substrate associated with synaptic plasticity. EMBO J 6:364l-3646.

Skene JHP (1989) Axonal growth-associated proteins. Annu Rev Neurosci $12: 127-156$.

Skene JHP, Willard M (1981a) Changes in axonally transported proteins during axon regeneration in toad ganglion cells. J Cell Biol 89: 86-95.

Skene JHP, Willard M (1981b) Axonally transported proteins associated with axon growth in rabbit central and peripheral nervous systems. J Cell Biol 89:96-103.

Steinbusch HWM, Nieuwenhuys R (1983) The raphe nuclei of the rat brainstem: a cytoarchitectonic and immunohistochemical study. In: Chemical neuroanatomy (Emson PC, ed), pp 131-207. New York: Raven.

Swanson LW (1976) The locus coeruleus: a cytoarchitectonic, Golgi and immunohistochemical study in the albino rat. Brain Res 1 10:3956.

Talmaciu RK, Hoffmann IS, Cubeddu LX (1989) Differential effects of phorbol ester on prefrontal cortex and striatal dopamine terminals: dependence on rate and duration of stimulation. J Pharmacol Exp Ther 251:1160-1165.

Tetzlaff W, Zwiers H, Lederis K, Cassar L, Bisby MA (1989) Axonal transport and localization of B-50/GAP-43-like immunoreactivity in regenerating sciatic and facial nerves of the rat. J Neurosci 9:13031313.

Wang HY, Friedman E (1987) Protein kinase C: regulation of serotonin release from rat brain cortical slices. Eur J Pharmacol 141:1521. 